UDC 821.161.1.09 Platonov A. https://doi.org/10.18485/ms_zmss.2021.100.40

\author{
Ханс Гюнтер \\ Университет Билефельда \\ hans.guenther@uni-bielefeld.de \\ Hans Günther \\ Universität Bielefeld \\ hans.guenther@uni-bielefeld.de
}

\title{
ПРОСТРАНСТВО И ВРЕМЯ: АНДРЕЙ ПЛАТОНОВ И ОСВАЛЬД ШПЕНГЛЕР
}

\author{
SPACE AND TIME: \\ ANDREY PLATONOV AND OSWALD SPENGLER
}

В русской литературе XX века вряд ли можно найти более тонкое чувство поэзии пространства, чем у Андрея Платонова. В то же время Платонов понимает, что безграничные просторы России представляют помеху на пути к развитию страны. В своих размышлениях об отношениях пространства и времени он находит близкие ему мысли в книге О. Шпенглера Закат Европы. Обоих авторов волнует представление о трагической необратимости времени. Главная мысль, которую Платонов развивает в своей статье «Симфония сознания» (1922) в соответствии с точкой зрения немецкого автора, это представление о пространстве как застывшем времени. В отличие от Шпенглера, Платонов, однако, делает акцент на революционном устремлении в будущее.

Ключевые слова: пространство, время, история, необратимость времени, революция, Закат Европы О. Шпенглера.

On the one hand Andrei Platonov has a deeper sense for the poetics of space than any other Russian author oft he 20th century, on the other hand he understands that the endless Russian space is an obstacle to the development of his country. In his reflection on the relationship between space and time he finds some ideas in Oswald Spengler's book The Decline of the West which, as he felt, were rather close to him. Both authors are concerned with the tragic irreversibility of time. The main idea, though, which Platonov develops in his essay „The symphony of consciousness“ (1922) in accordance with the German author is the idea of space as „frozen“ time. Unlike Spengler, however, he puts the stress on the revolutionary set off for future.

Key words: space, time, history, irreversibility of time, revolution, O. Spengler's The Decline of the West.

Продолжающаяся до сих пор дискуссия о связи между широтой пространства и ходом русской истории началась около 1830 г. с философа Петра Чаадаева. Он задавал основной тон в этом вопросе и отмечал преобладание географического фактора, «который властно господствует над нашим 
историческим движением, который красною нитью проходит через всю нашу историю» (Чаадаев 1989: 16). Согласно Чаадаеву, Россия живет «как бы вне времени» (Там же: 41), «без прошедшего и будущего, среди мертвого застоя» (Там же: 43), вследствие чего Россия не знает последовательных процессов развития, как другие европейские страны. И в творчестве Андрея Платонова, который был хорошо знаком с безграничными просторами степей воронежской губернии, проблема пространства занимает выдающееся место. Благодаря его деятельности в качестве инженера и мелиоратора он знал проблему отсталости крестьянской страны по собственному опыту. Электрификацию и индустриализацию он считал предпосылкой для того, чтобы «победить и пространство, эту первую причину дикости, голода и душевной нищеты» (Платонов 2004, 1/2: 235).

В книге Освальда Шпенглера Закаm Eвponь Платонов столкнулся с размышлениями о взаимоотношении пространства и истории, которые пересекались с его стремлением к преодолению косности пространства. Перевод шпенглеровской книги вышел в свет в 1923 г. и пользовался огромным успехом в России 1 . В своей статье «Симфония сознания (Этюды о духовной культуре)»² Платонов подхватывает некоторые идеи Шпенглера о связи пространства и времени. Основная мысль, которая появляется в самых разных вариациях, гласит: «То, что будет, есть время, то, что было, есть пространство. Иначе: пространство есть прошлое замерзшее время [...]» (Платонов 2004, 1/2: 221).

Отрицательная оценка пространства у Платонова объясняется тем, что с ним связаны насущные проблемы, с которыми он непосредственно сталкивается в своей работе. Пространство определяется им как «тень истории, ее отбросы, экскременты», как «время, съеденное историей», как «мрачное тюремное ущелье, тихий просторный белый каземат» (Там же: 224). В сопоставлении жизни людей в пространстве природы с голодным в зимнем поле Платонов бесспорно намекает на катастрофический голод на Волге 1921-1922 гг.

$\mathrm{B}$ «Симфонии сознания» понятия пространство и природа употребляются Платоновым - как и Шпенглером - почти как синонимы. Они охарактеризованы застоем времени, что находит свое выражение в романе Чевенгур в фразе «как было, как есть теперь» (Там же). Однообразность течения рек и смена времен года выступают как символы фатальной длительности. Они говорят о том,

что ничего не изменяется к лучшему — какими были деревни и люди, такими и останутся. Ради сохранения равносильности в природе, беда для человека всегда повторяется. Был четыре года назад неурожай - мужики

1 Скорее всего Платонов познакомился с содержанием книги Шпенглера через брошюру Освальд Шиенглер и Закат Европьl, вышедшую в 1922 г. См. комментарий: (Платонов 2004, 1/2: 399).

2 Статья была отвергнута газетой Воронежская коммуна. Рассказ «Эфирный тракт» (1927-1928), который содержит текст, во многом пересекающийся с «Симфонией сознания», также не был опубликован при жизни Платонова. 
из деревни вышли в отход, а дети легли в ранние могилы, — но эта судьба не прошла навеки, а снова теперь возвратилась ради точности хода всеобщей жизни. (Платонов 2009, 3: 45)

Ощущение времени у Платонова обычно сопровождается скукой и тоской. Апокалиптическое чувство застоя времени охватывает и героя рассказа «Сокровенный человек»:

Время кругом его стояло, как светопреставление, где шевелилась людская живность и грузно ползли объемистые виды природы. А надо всем лежал чад смутного отчаяния и терпеливой грусти. (Платонов 2009, 2: 206)

И у Шпенглера история и природа относятся друг к другу «как жизнь и смерть, как вечно становящееся время и вечно ставщее пространство» (Шпенглер 2003: 203). Пространство как застывшее время пребывает «вне времени, будучи оторванным от него, а тем самым — и от жизни. В качестве признанного свойства вещей в нем господствует продолжительность, отрезок умершего времени» (Там же: 217). В отличие от этого история «это современные события устремленности в будущее с оглядкой на прошлое. Природа находится по ту сторону всякого времени, имея в себе черту протяжения, однако без направления» (Там же: 204).

У обоих авторов человек стоит на пороге между временем и пространством. У Платонова эта позиция связана с революционной устремленностью в будущее. Творческий человек, как пишет Платонов,

стоит посреди - на зыбкой волнующейся грани времени и пространства и неутомимо, бессменно строит из жидкой пламенной лавы времени твердые холодные камни — пространство. (Платонов 2004, 1/2: 222)

Взгляд в даль ${ }^{3}$ устремлен на «неосуществленное пространство, т. е. будущее» (Платонов 2004, 1/2: 225), на сферу небывалого, «невозможного» 4 .

На судьбоносной дороге в неизвестное будущее человек сталкивается с тревожной проблемой необратимости времени, которая волнует и Шпенглера:

Это есть нечто неуловимое, превращающее будущее в прошлое, и это придает времени в противоположность пространству полную противоречий неоднозначность <...>. (Шпенглер 2003: 120)

В той же степени и для Платонова трагика времени связана с этой необратимостью. В Чевенгуре мы читаем:

Дванов почувствовал тоску по прошедшему времени: оно постоянно сбивается и исчезает, а человек остается на одном месте со своей надеждой на будущее. (Платонов 2009, 3: 335)

3 Шпенглер замечает: «У слова даль - красноречивый двойной смысл. В одном случае оно обозначает будущее, в другом - пространственное расстояние» (Шпенглер 2003: 142). У Платонова даль также обозначает и пространственный горизонт, и будущее.

4 Любовь к невозможному часто встречается в текстах Платонова 1920-1921 гг. Оно восходит к русскому символизму, в особенности к Вячеславу Иванову. См.: Günther 2020: 106-109. 
В неодержимой обратимости лежит как для Шпенглера, так и для Платонова «загадка» и «тайна» времени (см. Дмитровская 1997: 302-313). Герой романа Ювенильное море старается «постигнуть тайну и скуку исторического времени» (Платонов 2009, 2: 359), а нетерпеливый большевик Чепурный заканчивает «долготу истории срочным устройством коммунизма в Чевенгуре» (Платонов 2009, 3: 318), потому что он не выдерживает тайны времени.

\section{ЛИТЕРАТУРА}

Дмитровская, Мария. «Загадка времени: А. Платонов и О. Шпенглер». Логический анализ языка. Т. 9: Язык и время. Москва: Индрик, 1997: 302-313.

Платонов Андрей. Сочинения. Т. 1. Кн. 2. Москва: ИМЛИ РАН, 2004.

Платонов Андрей. Собрание. Москва: Время, 2009.

Чаадаев Петр. Статьи и письма. Москва: Современник, 1989.

Шпенглер Освальд. Закат Европы. Очерки морфологии мировой истории. Т. 1. Образ и действительность. Перевод И. И. Маханькова. Москва: Айрис Пресс, 2003.

Günther Hans. Revolution und Melancholie. Andrej Platonovs Prosa der 1920er Jahre. Berlin: Frank\&Timme, 2020.

\section{REFERENCES}

Chaadaev Petr. Stat'i i pis'ma. Moskva: Sovremennik, 1989.

Dmitrovskaya, Mariya. «Zagadka vremeni: A. Platonov i O. Shpengler». Logicheskij analiz yazyka. T. 9: Yazyk i vremya. Moskva: Indrik, 1997: 302-313.

Günther Hans. Revolution und Melancholie. Andrej Platonovs Prosa der 1920er Jahre. Berlin: Frank\&Timme, 2020.

Platonov Andrej. Sochineniya. T. 1. Kn. 2. Moskva: IMLI RAN, 2004.

Platonov Andrej. Sobranie. Moskva: Vremya, 2009.

Shpengler Osval'd. Zakat Evropy. Ocherki morfologii mirovoj istorii. T. 1. Obraz i dejstvitel'nost'. Perevod I. I. Makhan'kova. Moskva: Airis Press, 2003.

\section{Ханс Гинтер}

\section{ПРОСТОР И ВРЕМЕ: АНДРЕЈ ПЛАТОНОВ И ОСВАЛД ШПЕНГЛЕР}

\section{Резиме}

У руској књижевности XX века тешко да се може наћи тананије осећање за поезију простора од оног које поседује Андреј Платонов. Истовремено Платонов схвата да бескрајни простори Русије представљају сметњу на путу развоја земље. У својим размишљањима о односу простора и времена он проналази њему блиске мисли у књизи О. Шпенглера

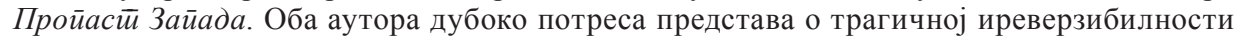
времена. Главна мисао, коју Платонов развија у свом чланку «Симфонија свести» (1922) у складу с тачком гледишта немачког аутора, јесте представа о простору као окамењеном времену. За разлику од Шпенглера, Платонов, међутим, ставља акценат на револуционарну окренутост ка будућности.

Кључне речи: простор, време, историја, иреверзибилност времена, револуција, Про$\bar{u} а с \bar{u}$ Зайада О. Шпенглера. 